\title{
A Virtual Ethnography Study: The Role of Cultural Radios in Campursari Music Proliferation in East Java
}

\author{
Zainal Abidin Achmad1, Rachmah Ida' ${ }^{2}$, Mustain ${ }^{3}$ \\ 1 Universitas Pembangunan Nasional Veteran Jawa Timur, Indonesia. \\ E-mail: z.abidinachmad@upnjatim.ac.id \\ 2 Universitas Airlangga, Indonesia. E-mail: rachmah.ida@fisip.unair.ac.id \\ 3 Universitas Airlangga, Indonesia. E-mail: mustain@fisip.unair.ac.id
}

\begin{tabular}{|c|c|}
\hline ARTICLE INFO & ABSTRACT \\
\hline $\begin{array}{l}\text { Keywords: } \\
\text { campursari music; } \\
\text { cultural proximity; } \\
\text { cultural radio; virtual } \\
\text { ethnography } \\
\text { How to cite: } \\
\text { Achmad, Z.A., Ida, R., } \\
\text { Mustain. (2020). A } \\
\text { Virtual Ethnography } \\
\text { Study: The Role of } \\
\text { Cultural Radios in } \\
\text { Campursari Music } \\
\text { Proliferation in East Java. } \\
\text { ETNOSIA: Jurnal } \\
\text { Etnografi Indonesia. 5(2): } \\
\text { 221 - 237. } \\
\text { DOI: } \\
\text { 10.31947/etnosia.v5i2.9787 }\end{array}$ & $\begin{array}{l}\text { Campursari music is a trend on the radio and a favorite of the people } \\
\text { of East Java, so it is shifting towards popular culture. This study aims } \\
\text { to uncover the proliferation of campursari music and the role of } \\
\text { cultural radios. This qualitative research uses a virtual ethnography } \\
\text { method, which focuses on the physical presence and virtual text } \\
\text { together. The subjects are technology (radio and communication } \\
\text { technology on the internet), humans (radio listeners), physical } \\
\text { interactions, and virtual interactions. Data collection used participant } \\
\text { observation through observation and interviews offline and online in } \\
\text { the form of various texts, writings, images, and audiovisuals on } \\
\text { Facebook, Twitter, WhatsApp, Instagram, and Youtube. The } \\
\text { informants of this study were four cultural experts, namely: Sumadi, } \\
\text { Anton Sani, Ibnu Hajar, and Juwono. This study carried out } \\
\text { participatory involvement for one year in the virtual world and } 30 \\
\text { days living in four cities: Surabaya, Nganjuk, Banyuwangi, and } \\
\text { Sumenep. } \\
\text { Manthous's campursari music is a fusion of pentatonic and diatonic } \\
\text { scales despite the addition of various musical instruments. It has } \\
\text { several sub-genres, including campursari janger, campursari } \\
\text { kendang-kempul, campursari keroncong dangdut, campursari } \\
\text { dangdut Madura, campursari jaranan dangdut, campursari dangdut } \\
\text { koplo, campursari dangduthip-hop, and campursari dangdut acoustic. } \\
\text { Cultural programs and campursari music reinforce the reliability of } \\
\text { radio to maintain local culture (Javanese, Madura, Using). They are a } \\
\text { means of maintaining local identities to stem global culture. No matter } \\
\text { how hard the invasion of foreign culture, can not disrupt the local } \\
\text { tastes of people. Campursari music proliferation is a modification to } \\
\text { traditional music to serve the tastes of the people, to avoid it from } \\
\text { extinction. Campursari music must be able to adapt to the current era. } \\
\text { The four radio cultures in East Java make campursari music a primary } \\
\text { commodity to attract radio listeners and as part of the lives of local } \\
\text { people. }\end{array}$ \\
\hline
\end{tabular}




\section{Introduction}

Radio broadcasting has a significant impact on the development of music and the music industry (Liebowitz, 2005; Schramm, 2006; Dertouzos, 2008; Achmad and Setiyanti, 2015). A plural phenomenon occurs, when the community like a type of music and becomes a trend on the radio, then it shifts towards mass culture (Boloka, 2003; Noone, 2013; Askin and Mauskapf, 2017). When listeners increasingly like radio because it broadcasts music that is becoming a trend, other radios are talkative to utilize this type of music in its broadcasts.

This phenomenon also occurs in various districts and cities in East Java. Since 2009 several commercial radios in East Java have made several programs and segment changes (Achmad and Alamiyah, 2015). Moreover, in the past five years, radio listeners have shown an increase in their enjoyment and interest in campursari music (Achmad and Ida, 2019). They started by adding or even replacing the music format with campursari music. The change in music format resulted in changes in radio segments and identities, including cultural radio, ethnic radio, Madurese radio, and campursari radio (Achmad, 2019).

This study aims to uncover the development and proliferation of campursari music in East Java, by examining four commercial radios that have cultural content in their broadcast programs, namely: radio Jodhipati FM in Nganjuk, radio Sritanjung FM in Banyuwangi, radio Nada FM in Sumenep and radio Media FM in Surabaya. The four radios studied were categorized as cultural radios because they had cultural broadcast hours, which were more than $50 \%$ of the total broadcast hours as well as having a music format that broadcasts more types of ethnic (Javanese, Using and Madurese) music (Achmad and Ida, 2019).

All cultural radios in this research, relies on the type of campursari music as one of the commodities, with different variations. Radio Jodhipati FM chooses to be consistent, only broadcasting classic Javanese campursari, but radio Media FM provides classical Javanese campursari and Javanese pop campursari at the same portion. Radio Sritanjung FM has domination in Banyuwangian (Using) campursari with additional Javanese pop campursari. Furthermore, Radio Nada FM broadcasts more Madurese campursari with additional Javanese pop campursari. Naming the types of classical Javanese campursari, Javanese pop campursari, using campursari, Madurese campursari are an agreement of the results of interviews with cultural experts, namely: Mr. Sumadi (Javanese cultural expert), Mr. Anton Sani (Campursari expert), Mr. Ibnu Hajar (Madurese cultural expert) and Mr. Juwono (Using cultural expert).

The naming of campursari music first appeared in 1953 by RM. Samsi, S. Dharmanto, and other artists at Radio Republik Indonesia (RRI) Semarang (Wiyoso, 2007a). Campursari music combines two different types of music, namely keroncong, with gamelan, which produces a pleasant mix of rhythm. At that time, campursari music was only to accompany Javanese songs with the instruments of the keroncong orchestra (guitar, ukulele, cello, bass, flute, violin) coupled with gender and siter (Sugiarto, 1999). Around 1978, those artists published a recording album of campursari to the public (Wadiyo, Wiyoso and Haryono, 2002). 
In the early 1990s, a Javanese music artist named Anto Sugiarto or better known as Manthous performed musical arrangements that combined Javanese songs accompanied by a mix of modern musical instruments with Javanese tradisional musical instruments (gamelan). Manthous had previously played a cellist in the campursari group led by S. Dharmanto and had learned the advantages and disadvantages of the campursari music. Then Manthous made several innovations so that campursari music reappeared in a different format. Manthous innovation is on the merger of gamelan instruments with modern musical instruments. In addition to the selection of musical instruments between gamelan and modern musical instruments, Manthous's most important innovation was in the process of aligning the pentatonic scale with the diatonic scale (Wiyoso, 2007a).

The gamelan instruments used by Manthous campursari are saron, demung, gendher, drum, siter, and gong. The modern musical instruments are a keyboard, ukulele, and electric bass. Sometimes Cak instruments (musical instruments such as small and fourstringed guitars) and Cuk (musical instruments such as small and three-stringed guitars). However, the elements of gamelan are more highlighted (Manthous, 1999). Manthous has the genius in functioning keyboard tones as harmonizers in combining pentatonic and diatonic scale (Kusnadi, 2006).

Manthous has the genius as that of Ki Nartosabdo, a legendary Indonesian leather puppeteer (dalang wayang kulit) who is dubbed as an artist with the talent Tri Karsa Budhaya, meaning an artist who can explore, develop, and preserve culture (Prasetyo, 2018). Manthous began his dedication to the development of Javanese culture when he founded the Campur Sari Gunung Kidul (CSGK) group in 1993, with the ideal and primary focus of producing campursari songs through recording for society. The society subsequently recognized the year of the founding of the CSGK group as a marker of the birth of campursari music.

Manthous expertise creates campursari music, able to align his musical work on par with the genres of pop, dangdut, rock, and keroncong music (Wiyoso, 2007b). As a great artist who was born in Gunung Kidul on April 10, 1950, and died on March 9, 2012, Manthous was not spared from various awards, including: as an innovative artist from the Indonesian Journalists Association in 1997, the Charter of Art Awards from Sri Sultan Hamengku Buwono X in 1999, and the 2002 Ethnic Award.

Manthous campursari music has a standard (the main requirement) that must exist, namely the combination of pentatonic and diatonic scales despite getting additional various musical instruments. While the use of Javanese in the lyrics is not a standard (Wadiyo et al., 2011), the goal is that campursari music can develop by using the lyrics of other languages. The lyrics in the campursari song generally use simple language so that it is easily heard and understood at all levels in society (Supanggah, 2003). 
Historically, the CSGK group has produced two famous record albums, namely Kanca Tani and Nyidam Sari. Furthermore, on every album, there is always innovation in the form of adding traditional music instruments from other ethnic groups in Indonesia, with the aim that the campursari music will be unique and creative. In total, Manthous and CSGK have released ten albums. Six albums specifically provide campursari music, and the other four albums present processed keroncong and Javanese pop music. The division of music types in a separate album is to show the distinction between campursari, keroncong, and Javanese pop to the people (Wiyoso, 2007a). Researchers argue that Manthous seeks to provide a firm boundary line to distinguish the campursari genre of his creation from other types of music. In the latest developments, Manthous campursari music has become root for the proliferation of derivative campursari music. This proliferation occurs quickly because the existence of cultural radios facilitates it. For this reason, this study aims to explain the proliferation of Campursari music and the role of cultural radios in it.

\section{Method}

This qualitative research uses a virtual ethnographic method that refers to Christine Hine's ideas that focus on the physical presence and virtual text together (Angelone, 2018). Based on research subjects in the form of technology (radio and communication technology on the internet), humans (radio listeners), physical interactions, and virtual interactions between the two. The focus of virtual ethnography is on various texts, such as text, images, audiovisuals that are on the internet (Kriyantono, 2020, p. 200) while the focus of the data obtained in various texts, such as text, images, audiovisuals found on Facebook, Twitter, WhatsApp, Instagram, and Youtube.

Based on location, this study collects data from (1) real locations, namely offices and studios of cultural radios (regions or regions), locations of informants' homes or workplaces, locations of off-air radio activities, locations of informants associating; (2) virtual locations, namely: web pages, Facebook accounts, Instagram accounts, Youtube channels, and WhatsApp. Moreover, do a combination of data collection through observation and interviews because the combination of both can dig up data more abundant and more complete (Achmad, Juwito and Saud, 2020).

Interviews are carried out offline in the form of discussion, chat, question and answer and chat with informants as the subject under study (Driskell and Lyon, 2002; Sade-Beck, 2004; Driscoll and Gregg, 2010; Shumar and Madison, 2013; Angelone, 2018). Researchers mainly use chat on WhatsApp to do intensive online interviews. The reason for choosing observatiom and interview with participant observasion is to examine and to identify the behavior of the inhabitants of the virtual world (Achmad and Ida, 2018).

Observation enrolls in the real world (offline observation) and the virtual world (online observation). Offline observations can help researchers determine information as background, limiting problems, and frame the hypotheses needed (Wimmer and Dominick, 2014, p. 128). Online observations make it easy for researchers to record and analyze data simultaneously and repeatedly. This activity is referred to as iteration or recursive. 
Some reasons for choosing participant observation techniques, because (1) the importance of understanding to social context, (2) the importance of getting direct experience, (3) the importance of finding sensitive and closed information, (4) the need to see things that are not observed by others, (5) the need to find things outside the subject's perception, (6) the need to collect rich data through personal impressions (Fine, 2003; Fay, 2007; Wimmer and Dominick, 2014, p. 142; Achmad and Ida, 2018).

Table 1. Source of Virtual Ethnographic record and document

\begin{tabular}{|c|c|c|}
\hline RADIO NAME & Facebook Account & $\begin{array}{l}\text { WhatsApp Group or FB } \\
\text { Group }\end{array}$ \\
\hline Radio NADA FM & $\begin{array}{l}\text { https:// www.facebook.com/profile.ph } \\
\text { p?id=100012074612446 }\end{array}$ & PENIKMAT NADA FM \\
\hline Radio Sritanjung FM & $\begin{array}{l}\text { https:// www.facebook.com/profile.ph } \\
\text { p?id=100010926105561 }\end{array}$ & $\begin{array}{l}\text { SRITANJUNG FM } \\
\text { FANS }\end{array}$ \\
\hline Radio Jodhipati FM & $\begin{array}{l}\underline{\text { https://www.facebook.com/jodhipatif }} \\
\underline{\mathrm{m} /}\end{array}$ & $\begin{array}{l}\text { SANAK KADANG } \\
\text { JODHIPATI }\end{array}$ \\
\hline Radio Media FM & $\begin{array}{l}\text { https://www.facebook.com/Media90.1 } \\
\text { FM/ }\end{array}$ & $\begin{array}{l}\text { https://www.facebook.c } \\
\text { om/groups/32063597360 } \\
90803\end{array}$ \\
\hline Mr. Sumadi & $\begin{array}{l}\text { https://www.facebook.com/soma.jodh } \\
\text { inati }\end{array}$ & \\
\hline Mr Juwono & https://www.facebook.com/kang.ju.98 & \\
\hline Mr. Ibnu Hajar & https://www.facebook.com/ibnu.h.new & \\
\hline
\end{tabular}

Source: Data Primer.

Researchers collect data on the role of cultural radios in the dissemination of traditional music and local songs and the responses of cultural figures in the development of music mix. As a participant, the researchers carry out the following activities: (1) observing studio life and engaging in broadcast activities, (2) observing and engaging in the interaction between cultural leaders and radio workers, (3) observing the social media accounts of culture radios and cultural leaders (Facebook and WhatsApp). This study carried out participatory involvement for one year in the virtual world and 30 days living in four cities: Surabaya, Nganjuk, Banyuwangi, and Sumenep. Observation of the Facebook account and interview aims to explore information about the development of Campursari music. Meanwhile, Anton Sani (campursari music observer) does not have a Facebook account.

This study got easy access, because the researchers fulfill the main requirements as a virtual ethnographer, namely giving a frank statement to the research subjects about conducting research. The number of informants in this study adjusts the need to compare the experiences of informants, with consideration of differences in age, occupation, choice of interaction channels, and length of time visiting the virtual world (Hine, 2000; Schaap, 2002; Hair and Clark, 2003; Achmad and Ida, 2018). 


\section{Results and discussion}

Since the 2000s until now, Campursari has experienced a shift in the meaning and expansion of music. Campursari music is a collaboration or a merger between diatonic scales (modern musical instruments) and pentatonic scales (gamelan instruments) (Wiyoso, 2007a; Haryono and Ganap, 2011; Saputri, 2015; Kobi, 2017). However, now every song that uses Javanese lyrics is considered by the public as campursari music (Achmad and Ida, 2019). Even though the music has a sound that similar with traditional instruments, but there is no combination of diatonic and pentatonic scales. This shift makes the original campursari lovers' community disappointed. However, some other traditional music communities like to hear it. Because it opens up opportunities for the growth of the music industry, local recording businesses, local language songwriters, and radio play an essential role as the primary media of its development, bridging the younger generation to love local language songs, groups local pop and Malay orchestras (Orkes Melayu) have sprung up, local advertisements are multiplying.

The results of the discussion through WhatsApp with three cultural experts and tracing the Facebook accounts of cultural radios, all agreed that the original definition of Campursari music was the flow of music created by Manthous. Therefore, Manthous received an assessment from the broader community as the father of campursari, because he who gave birth to and created music campursari. Now, the music of any kind, but using Javanese lyrics refers to as a sub-genre of campursari.

Figure 1: Radio Jodhipati FM is the only cultural radio in East Java that conducts live streaming campursari via the Youtube channel.

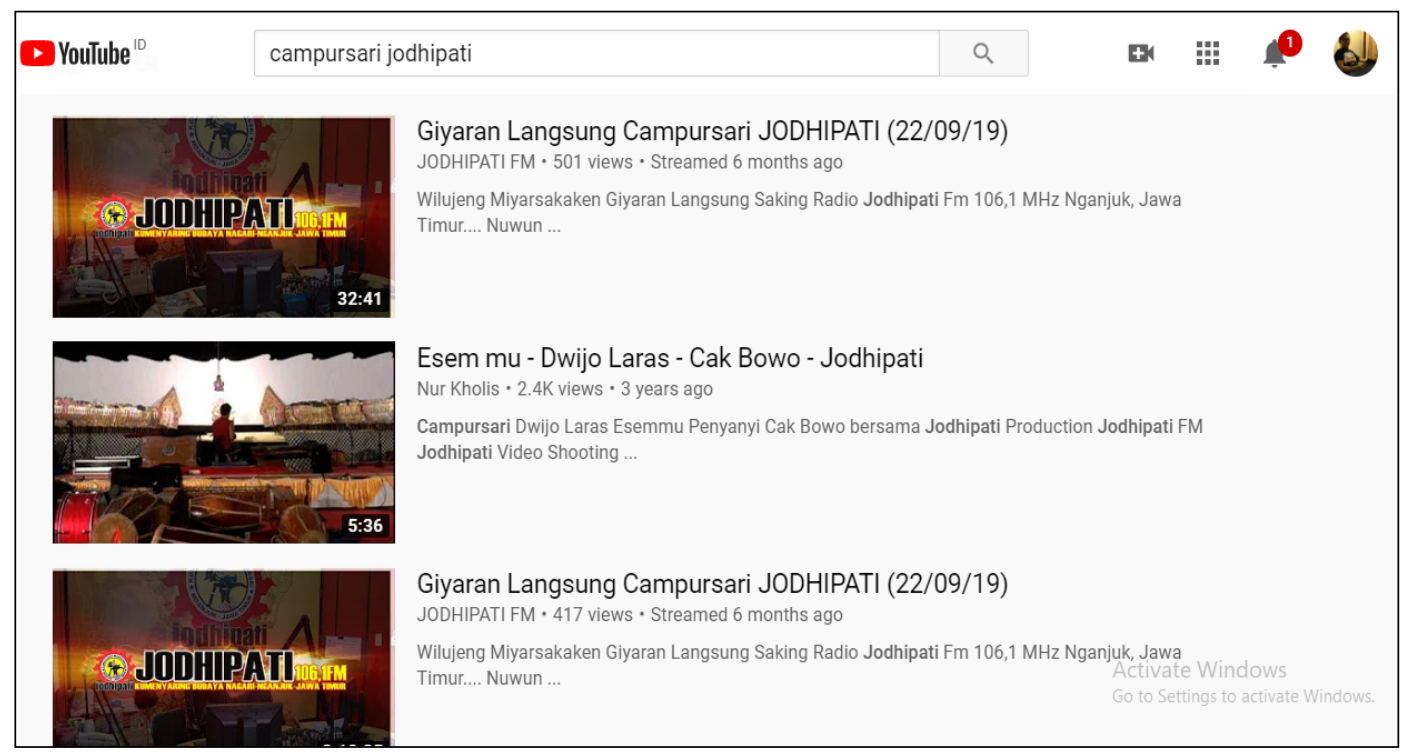

Source: Youtube.

On radio Jodhipati FM, Manthous campursari gets as a classic or standard campursari. Although there are elements of modern musical instruments, Manthous campursari music has a robust Javanese style, and it has underlying musical footing is Javanese gamelan. Radio Jodhipati FM ignores contradictions in the early history of the birth of the Manthous campursari. At first, campursari considered violating the rules of the 
cultivation of good music. In the past, the birth of Manthous campursari was thought to be due to an economic motive or just money reasons, damaging the gamelan grip, ignoring the quality of music, and being lowly (Wiyoso, 2007a).

As Sumadi (informant 1, interview on 25 March 2018) emphasized, radio Jodhipati FM was more appreciative of the success of Manthous campursari. Because radio listeners spread abroad as Javanese, among others from Suriname, Hong Kong and Saudi Arabia favor the music. The type of music with Javanese lyrics is called Campursari Jowo mixed music. Although many people define it as campursari, for radio Jodhipati FM, the songs are not campursari, because they have too mixed elements of their musical instruments. Even though the lyrics are in Javanese, but the musicality is mixed. They are dangdut, keroncong, rock, reggae, and hip kop. Campursari music that broadcast by Jodhipati FM radio was only Manthous's classic campursari. Jodhipati FM insisted not to broadcast Jowo mix music because it was considered to have too many elements of modern music and left Javanese gamelan.

Giving name campursari is not a problem on radio Media FM Surabaya. This radio does not care whether the broadcasted campursari is classic or modern. It also does not matter the process of composing the song, whether by combining elements of gamelan music with modern instruments or only produced through a keyboard or organ. The reason is that classic campursari (elements of style) and modern (Javanese pop, dangdut keroncong, campursari dangdut koplo, dangdut hip-hop), have their fans and audience segments. Classic campursari in the style of Manthous and Javanese pop (modern music with Javanese lyrics) are all included in a program called campursari.

For radio Media FM, the type of music is not very important, because the sub-streams of campursari today have widened beyond the limits of music flow. Campursari, who was born Manthous, paved the way for the development of the type of music rooted in it. Therefore, that campursari music popularized by Didi Kempot (keroncong dangdut) to Koplo campursari (OM. Sera, OM. Monata, and OM. Sonata) or hip-hop campursari (NDX AKA), are all broadcast by radio Media FM. More critical for radio Media FM is paying close attention to the content of the lyrics in each song. Anton Sani (informant 2) explained that radio Media FM has banned broadcasting campursari songs whose lyrics contain disgusting elements since the early 2000s. Radio FM Media will never broadcast swear words, dirty words, demeaning humanity, degrading women, harassing disabled groups, harassing work or professions, sexual abuse, domestic violence, ethnic bias, physical shaming, and religious abuse.

Campursari broadcasts on radio Media FM divide into two segments. The first segment broadcasted at 18.00-22.00 WIB was all campursari songs categorized as Javanese pop, dangdut keroncong, campursari hip-hop, dangdut janger, campursari Using, and campursari koplo. In short, this segment provides any music whose lyrics are Javanese. The second segment broadcasted at 22.00-02.00 WIB is all music categorized by Javanese music, both tayub and cokekan. Javanese music using drums, gender, siter and gong instruments, or with the addition of saron barung and demung. Even if there is a campursari, only broadcast Manthous's work. 
On radio Sritanjung FM, it does not matter what type of music broadcast is campursari or not. Because on this radio, all types of music that uses local language lyrics (Javanese or Using) called ethnic music. Radio Sritanjung FM is acutely aware of the shift in people's tastes towards arts and culture programs, as they understand that change is a necessity. Radio Sritanjung FM had experienced while repositioning twice.

At the first year of radio Sritanjung FM establishment, they declared as a radio of information and dakwah (preacing of Islam) then turned into ethnic radio with the dominance of the Using and Madurese language broadcasts, and dangdut music as a dominant music. Finally, there is a change to ethnic radio with the dominance of ethnic music and dangdut music. They only broadcast dangdut of Rhoma Irama, on the grounds of maintaining the typical radio Sritanjung FM program, which from the start stood always presenting Rhoma Irama dangdut songs. Using campursari, songs and Javanese campursari songs dominate the rest of the music.

These changes on radio Sritanjung FM are a manifestation of the dynamics in radio life. Campursari shows us its changing process. Music directors on radio Sritanjung FM well understand Campursari music originating from Java and developing in various subgenres (keroncong dangdut, Javanese pop, dangdut janger, hip-hop campursari, koplo campursari, and acoustic dangdur campursari). Radio Sritanjung FM, then maximize the sub-campursari has a nuance of Using music.

The next explanation is the result of researchers' observation of several variations of campursari music proliferation. Some campursari sub-genres, including:

\section{- Campursari Janger}

One of the fertile sub-genre of campursari in Banyuwangi is Janger. This music has the closest relation with Balinese gamelan tones that sounded smart. In addition to the keyboard, gamelan instruments used are reyong (a type of bonang), kethuk, flute, and kendhang (Sinaga, 2016). The Using dialect has generally used to sing the janger songs.

Janger itself is a traditional theater art, as ketoprak, ludruk, shadow puppets, and kentrung (Anoegrajekti, 2014). Janger theater in Banyuwangi is still popular with the public. Some of Janger Banyuwangi's traditional arts groups that still survive, among others: Tiara Nusa Dewa (Yosomulyo-Gambiran), Setyo Kridho Budoyo (Parijatah Wetan-Srono), and Budi Utomo (Setail-Genteng) (Sugiyanto, Sumarno and Nurhidayah, 2016).

Based on its history, the traditional art of Janger Banyuwangi was born from the process of cultural acculturation, namely Javanese culture, Balinese culture, and the original culture of Banyuwangi (Using). Uniquely, the three cultures unite in it without losing the characteristics of each culture. It so-called, Janger is a traditional hybrid art (Anoegrajekti, 2014). Javanese culture in Janger's art displayed in the use of languages, musical instruments, and songs. Balinese culture in the art of Janger, raised in the use of musical instruments, clothing, and dance. Furthermore, the Using culture in Janger displayed on the use of language in comedy or slapstick scenes as well as on songs sung in additional entertainment rounds. Since its history is mixed, it is not surprising that 
Janger is categorized as a well-developed campursari in Banyuwangi (interview with Juwono, informant 4, 13 November 2018).

In line with the development of campursari music, Balinese gamelan music is added to dangdut songs with Javanese lyrics, Using and a mixture of the two languages. Several types of Janger gamelan used for inclusion in campursari songs include reong, pantus, saron, peking, jagogan or jegogan, gong, kempul, kethuk, kecer/kecrek, Balinese drum, Banyuwangi drum, and flute (interview with Juwono). ${ }^{1}$

\section{- Campursari Kendang-kempul}

Starting from the strong popularity of dangdut music in the 1980s, the Banyuwangi music artists spearheaded by Sutrisno, together with Wiroso, Suroso, and Hawadin. They made a new music genre by absorbing dangdut elements, by replacing the instrument of ketipung, replaced by the Banyuwangi drum, named Kendang-kempul (Diawangsa, 2014). Kendang-kempul was later recognized and known as dangdut Banyuwangian. This effort was supported by the Regent of Banyuwangi at the time, Djoko Supaat Slamet (Nurullita, 2015).

Kendang-kempul music, which was consistently developed by Sutrisno from Genteng sub-district, the instruments contained herein are not entirely original Banyuwangi gamelan but are a combination of traditional and modern instruments. Gamelan elements, consisting of drum plaque, kluncing (triangle of iron wire), kethuk, gong, and kempul (small gong). Elements of modern instruments include the keyboard, melody guitar, and bass guitar (Siwi, 2015).

If we pay attention to the history of kendang-kempul music, its birth has similarities with campursari music. Kendang-kempul Banyuwangi is a mixed orchestra between modern instruments and traditional music instruments ${ }^{2}$. Uniquely, for listeners of Sritanjung FM radio, they more generally assume that the kendang-kempul is a campursari music (interview with Juwono, informant 4). ${ }^{3}$

At present, kendang-kempul music has developed to be modern. More and more kendang-kempul songs collaborate with other musical genres, such as keroncong, reggae, and dangdut. Collaboration with dangdut is the most powerful so that it is famous throughout Indonesia because it produces dangdut koplo music as a blend of pounding ketipung dangdut and kendang-kempul (Weintraub, 2013).

\section{- Campursari Keroncong Dangdut}

Didi Kempot is the first artist who popularized this campursari sub-genre. This musical variant is not included in the campursari category, because there is no gamelan mix of pentatonic instruments at all. So some people named it as Javanese Pop. Didi Kempot himself admitted that his music was called Congdut (a mixture of keroncong and dangdut), with the dominance of music from the ukulele keroncong and the ketipung dangdut. Embedding Didi Kempot as a campursari singer, because the producer labeled

\footnotetext{
${ }^{1}$ Here is one of the campursari janger songs: https:/ $/$ www.youtube.com/watch?v=cjRvg78YFoM

${ }^{2}$ One of the links is https://www.youtube.com/watch?v=DKXzNamGTUQ.

${ }^{3}$ We can use this link to listen to campursari kendang-kempul with pop nuance: https://www.youtube.com/watch?v=k0BnFDH96LY.
} 
campursari at the launch of Didi Kempot's first album (Wadiyo, Wiyoso and Haryono, 2002; Wiyoso, 2007b). The reason is that the album was taken up by the triumph of Campursari's music at that time. At the same time, similar forms of campursari began to be recognized, namely: a mixture of gamelan with keroncong, and a mixture of gamelan with dangdut.

Although many criticisms appear on the development of campursari music that seems limitless, many parties agree with the argument of researchers, that campursari music can revitalize various traditional music on the islands of Java and Madura and become bridge music between generations (the same statement from two informants, Mr. Sumadi and Mr. Anton Sani). People interpret that every song that uses Javanese lyrics is campursari music, and does not care whether the music is a mix of diatonic and pentatonic scales or not (Tallapessy, Setiawan and Subaharianto, 2016; Kobi, 2017).

\section{- Campursari Dangdut Koplo}

The dangdut music combining with gamelan has been going on since the 1980s. At that time, dangdut music collaborated with traditional Sundanese gamelan music (jaipong music) and other traditional music, namely: Javanese, Minangkabau, and South Tapanuli (Muttaqin, 2006). Dangdut, at this time, combines with local musicality, both in collaboration with instruments, languages, melodies, and vocal techniques. Dangdut which is associated with locality and has a regional character, named "Dangdut Ethnic" (Setiaji, 2017). Dangdut develops with regional language lyrics and delivers to specific ethnic communities. Some of the dangdut ethnic variants are: dangdut Minang from West Sumatra, Sundanese pong-dut from West Java, Tarling is from Cirebon, Koplo Jawa is from East Java, and in Banjarmasin, it is named dangdut Banjar (Weintraub, 2013). Moreover, what is currently developing is Dangdut Using or Campursari Kendangkempul from Banyuwangi (interview by Mr. Anton Sani, informant 2).

Dangdut Koplo has the most progressive development which emerged from the East Java region around the 2000s. Some people assume that Koplo dangdut was born due to the saturation of society due to the dominance of Disco Dangdut in the 1990s due to the influence of House Music (Saputro and Sitorus, 1994), thus drowning out the diversity of dangdut ethnic.

Dangdut koplo began to emerge since the entry of elements of the kendang-kempul instrument from Banyuwangi East Java, Javanese gamelan, and Jaranan from Nganjuk and Kediri. The combination of various instrumentation and musical tones by the East Java dangdut musicians gave birth to the distinctive Dangdut Koplo music with a prancing style on the singer's shake and the beat of the music (Yoga, 2013).

Some of the Malay Orchestras (OM) who dominated the East Java region at this time, among others: OM. Sagita (Nganjuk), OM. New Pallapa (Sidoarjo), OM. Sonata (Jombang), OM. Monata (Mojokerto), OM. Sera comes from the abbreviation of Selera Rakyat (Gresik), OM. Evita (Gresik), OM. Putra Dewa (Tuban).

\section{- Campursari Jaranan Dangdut}

At the same time as the emergence of campursari dangdut koplo, another dangdut ethnic also appeared in the area around Nganjuk, Ponorogo and Probolinggo which 
included elements of musical instruments in the traditional art of jaranan so that they became "Jaranan Dangdut" or "JanDut" popularized by OM. Sagita (Nganjuk) and OM. Sonata (Jombang) (Setiaji, 2017).

Jaranan music is prevalent in East Java because it has the characteristics of dynamic music with a pounding drumbeat. This music is the result of the adoption of the jaranan dance performance, a folk performance that directly confronts the mass of the audience. To maintain the interest of the audience, the drummer hits the drum agile, attractively, and in a row. Besides, dancers and spectators to have enthusiasm and passion. The dynamic of jaranan music then combined with koplo dangdut (interview with Mr. Sumadi, informant 1).

Almost all Malay orchestras can now play jaranan dangdut music, but OM. Sagita was the first to introduce it. Sagita is a Malay music orchestra from Pace District, Nganjuk Regency East Java Province. Their music is a combination of dangdut koplo with the art of Jaranan (Kuda Lumping). The combination of these musical elements is called Jaranan Dangdut (Jandut). The unique jargon attached to this musical group is the word "Assololley. Icy-Icik Eheeem" (Juwariyah and Dharmawanputra, 2017).

\section{- Campursari Dangdut Hip-Hop}

Sub-genre Dangdut Hip-Hop firstly introduced by a group called NDX AKA FAMILIA. This group features dangdut music with a touch of hip-hop music that comes from America. The uniqueness of NDX AKA is its power to maintain local Javanese elements with $75 \%$ of the lyrics using Javanese so that the dangdut song serenely and harmoniously heard. The hallmark of NDX songs is the presence of solid pieces of rapstyle lyrics in all of its songs (Putradarma, 2017).

Rap is one of the markers of Hip-hop cultural elements. Hip-hop itself is a cultural movement that began to grow around the 1970s, which was developed by AfroAmerican and Latin-American communities (Bularzik, 2013). Hip-hop and rap are an inseparable unity. Rap is a vocal technique that uses words quickly, while the culprit is called Rapper (Blanchard, 1999). 4

\section{- Campursari Dangdut Madura}

The Campursari Dangdut Madura initially were not created by artists from the island of Madura but originated from Situbondo. Starting from the large Madurese speaking population in the horseshoe area that stretches from Situbondo, Bondowoso, Jember, Probolinggo, Pasuruan, Bangkalan, Sampang, Pamekasan, and Sumenep. These artists use local recording studios to produce songs and music, then disseminate and sell to local people (Hidayatullah, 2015). Generally marketed in the form of a compact disc (CD) in mp3 format and video compact disc (VCD) in mp4 format. The marketing chain is quite simple, through booths selling cassettes, CDs, and VCDs in traditional markets. ${ }^{5}$

\footnotetext{
${ }^{4}$ To enjoy dangdut hip hop songs: https:// www.youtube.com/channel/UC-acDc3cmE2QnxVu8To57BA. One of the dangdut rap bands that are orbiting is GMLT or GEMLITERS: https://www.youtube.com/channel/UCP9G7_O1NCdV6gsREG_r4Mg

${ }^{5}$ An example of a Madurese dangdut song is in the following link: https://www.youtube.com/watch?v=bm9SYvhsfeI.
} 
The definition of Campursari dangdut Madura is dangdut music with Madurese lyrics ignoring the elements of the musical instruments used. Traditional Madurese instruments do not have roots in musical history that stand-alone. Madurese musical art is closer to Javanese gamelan. Gamelan Madura is a levy of Javanese gamelan and is the work of a royal nobleman who has a kinship with the Javanese nobility. The relationship between the Sumenep palace (and also the Bangkalan palace) with the Solo palace (especially in the Mataram era) made it possible for the types of arts to be included such as gamelan, Macapat song, Tari Topeng, and Tayub (Kuntowijoyo, 1987; Hidayati, 2012).

Therefore, it is not surprising that radio Nada FM categorizes Dangdut Madurese as campursari music as the name for dangdut song with Javanese lyrics. For the people of Sumenep, we are not concerned about the type of music. Every dangdut song and the lyrics are in Madura; we give the name campursari. Every time there is a request for a dangdut Madura song in the ethnic music program, we call it campursari (interview with Ibnu Hajar, informant 3, 17 November 2017).

In some campursari dangdut Madurese, songs also insert some local instruments. When we listen to some of Madura's dangdut campursari songs more thoroughly, there are tong-tong and saronen sound inserts. Tong-tong is a small size kentongan (a kind of percussion made from the base of the siwalan tree trunk). Saronen is a kind of trumpet; it has a wing covering the mouth of the blower and has a shape like a mustache. The length of the saronen is around $40 \mathrm{~cm}$ (interview with Ibnu Hajar, informant 3, 17 November 2017).

In the current development, saronen has become very popular with the people and has become a characteristic of Madura music. Saronen can accompany various songs, such as keroncong, dangdut, pop, rock, and folk songs if saronen displays in full orchestra with nine other instruments, namely: one saronen, one large gong, one kempul, one large kenong, one middle kenong, one small kenong, one korca, one large drum and one drum dik-gudik (small) (Hidayati, 2012). The main strength of Saronen in full orchestra is to create a cheerful atmosphere.

\section{- Campursari Dangdut Acoustic}

A band first introduced this new campursari sub-genre from Yogyakarta named "Guyon Waton." This new band pioneered a unique music genre because it processed music with the 'dangdut acoustic' genre, a new genre in the Indonesian dangdut music scene. The combination of a relaxed acoustic rhythm and the strains of this dangdut was created by five personnel "Guyon Waton," namely Faisal Bagus Ibrahim (Vocal), Achmad Arifin (Guitar), Hieronimus Ferry Widiyatmoko (Melodi), Ndika Rismaya Pelma Arga (Ukelele) and Ahmad Wahyu Susilo Jati (Ketipung). This dangdut acoustic campursari produces solemn music and is very enjoyable to accompany swaying.

The public began to get to know the band Guyon Waton when achieving success with a song called "Korban Janji." People in Yogyakarta, Central Java, East Java, and Indonesian music lovers love the song. Moreover, the number of viewers of the song 'Korbanjanji' on Youtube has reached 66 million. While the number of official YouTube channel subscribers reaches 1.56 million, it is no wonder that some cultural radios in East Java 
played songs from Guyon Waton. The superiority of the band Guyon Waton is that it is in addition to its acoustic music, the lyrics are full of meaning with simple sentences. ${ }^{6}$

\section{Conclusion}

Radios program containing local culture are efforts to maintain cultural existence, amid the onslaught of popular entertainment programs. The practice of broadcasting by the four radio cultures enriches the analysis of radio as a reliable medium for maintaining local culture (Bosch, 2008, 2014; Mu-azu and Shivram, 2017; Uimonen, 2017; Zein and Dewi, 2019). The presence of cultural programming broadcasts on the radio affirms the argument about the need to maintain local and national identities to stem foreign or global cultures (Morley and Robins, 1995). At the same time, it confirms Rachmah-Ida's analysis that the invasion of a foreign culture cannot disrupt local tastes because local tastes are the stereotype of local cultural products (Ida, 2009).

The existence of cultural radio listeners to foreign countries does not merely prove the validity of the perspective of cultural resistance when someone who lives outside the national border needs media content that is appropriate to their place of origin. Another perspective that occurs is cultural proximity when Javanese cultural programs on Jodhipati FM radio become a necessity for some residents in Suriname. Suriname residents adapt and negotiate with foreign cultures (Javanese Culture), which are allied or have geo-cultural or geo-linguistic closeness (Sinclair, Jacka and Cunningham, 2000). The Javanese cultural program from Jodhipati FM radio received by the citizens of Suriname enriched the study of the role of radio in cultural proximity in Asian countries. Most cultural studies in Asia focus more on the role of television, film, and music (Straubhaar, 1991; Iwabuchi, 2002; Shim, 2006; Ida, 2008; Shim, Heryanto and Siriyuvasak, 2010; Achmad, Mardliyah and Pramitha, 2018).

Furthermore, the results of this study support Rachmah Ida's argument that cultural proximity influences the consumption of popular culture. The four radio cultures in East Java cleverly favor local culture as originality that attracts radio listeners. Moreover, the fourth radio culture has a role as a powerful media to "popularize" local culture as part of the lives of local communities (Ida, 2017).

Cultural radios in East Java play an essential role in the proliferation of campursari music, because: (1) it has succeeded in encouraging the process of cultural unification and renewal through the spread of campursari music as a commodity that is consumed in bulk by radio listeners, (2) successfully defending and strengthening local identity (Javanese, Madura and Using) through broadcasting campursari music that is characterized by their respective ethnicities, (3) succeeded in engaging culturalists and artists in designing music programs and local culture

Campursari music proliferation is a modification to traditional music to serve the tastes of the people, to avoid it from extinction (Jurriens, 2006). Campursari music must be able

\footnotetext{
${ }^{6}$ To enjoy the Guyon Waton, please use this link: https://www.youtube.com/channel/UCxb2XwbJ0W5NUecmJIEHNxg/featured.
} 
to adapt to the current era. The four radio cultures in East Java make campursari music a primary commodity to attract radio listeners and, as part of the lives of local people.

\section{Acknowledgments}

This research is a part of findings in a doctoral research project on social science studies in the Faculty of Social and Political Sciences, Universitas Airlangga, SurabayaIndonesia. This research did not receive any specific grants from funding agencies in the public, commercial, or non-profit sectors.

\section{Conflicts of interest}

Author declares no conflict of interest.

\section{References}

Achmad, Z. A. (2019) “Integrasi Program Dakwah dan Budaya: Studi Etnografi Virtual Mediamorfosis Radio Nada FM Sumenep Madura," Jurnal Komunikasi Islam, 09(2), pp. 238-263. doi: 10.15642/jki.2019.9.2.239-263.

Achmad, Z. A. and Alamiyah, S. S. (2015) “Relation Between Political Economic of Media with the Strategies for Radio Positioning to Maintain the Existence of Commercial Radio (Case Study of JJFM Radio in Surabaya)," in International Conference on Democacy and Accountability (ICoDA). Surabaya: Faculty of Social Sciences and Political Sciences, Universitas Airlangga, pp. 188-193.

Achmad, Z. A. and Ida, R. (2018) “Etnografi Virtual Sebagai Teknik Pengumpulan Data dan Metode Penelitian," The Journal of Society E Media, 2(2), pp. 130-145. doi: 10.26740/jsm.v2n2.p130-145.

Achmad, Z. A. and Ida, R. (2019) "The shifting role of the listeners in the mediamorphosis process of culture radio: A case study of Jodhipati 106.1 FM," Masyarakat, Kebudayaan dan Politik, 32(3), p. 240. doi: 10.20473/mkp.v32i32019.240250.

Achmad, Z. A., Juwito, J. and Saud, M. (2020) “THE LOCAL CREATIVE ADS ON SRITANJUNG FM TO INCREASE FINANCIAL REVENUE DURING COVID-19 PANDEMIC," Bricolage: Jurnal Magister Ilmu Komunikasi, 6(2), pp. 135-146.

Achmad, Z. A., Mardliyah, S. and Pramitha, H. (2018) “The Importance of Parental Control of Teenagers in Watching Anime with Pornographic Content on the Internet," in Proceedings of the International Conference on Contemporary Social and Political Affairs (IcoCSPA 2017). Paris, France: Atlantis Press, pp. 81-84. doi: 10.2991/icocspa-17.2018.22.

Achmad, Z. A. and Setiyanti, O. W. (2015) "The Effectiveness of Use of Soundcloud Application for Promoting Pop Punk Songs and Music," in Bali International Seminar on Science and Technology. Denpasar: BISSTECH, pp. 59-64. Available at: www.engadget.com/2012/12/07/editorial-.

Angelone, L. (2018) "Virtual Ethnography: The Post Possibilities of Not Being There," Mid-Western Educational Researcher, 31(3), pp. 275-295.

Anoegrajekti, N. (2014) "Janger Banyuwangi dan Menakjinggo: Revitalisasi Budaya," Literasi, 4(1), pp. 116-127.

Askin, N. and Mauskapf, M. (2017) What Makes Popular Culture Popular? Product Features and Optimal Differentiation in Music, American Sociological Review. doi: $10.1177 / 0003122417728662$.

Blanchard, B. (1999) "The Social Significance of Rap \& Hip-Hop Culture," Journal of Poverty $\mathcal{E}$ Prejudice: Media and Race, pp. 1-10. Available at: http://hiphoparchive.org/sites/default/files/the_social_significance_of_rap_hi 
p_hop_culture.pdf.

Boloka, G. (2003) "Cultural Studies and the Transformation of the Music Industry: Some Reflections on Kwaito," in Wasserman, H. and Jacobs, S. (eds.) Shifting Selves: Postapartheid Essays on Mass Media, Culture and Identity. Cape Town: Kwela Books, pp. 97-108.

Bosch, T. E. (2008) "Kwaito on Community Radio: The Case of Bush Radio in Cape Town, South Africa," The World of Music, 50(2), pp. 75-89. Available at: http:// www.jstor.org/stable/41699828.

Bosch, T. E. (2014) "Commercial music radio, race and identity in South Africa," Media, Culture and Society, 36(7), pp. 901-915. doi: 10.1177/0163443714536076.

Bularzik, E. (2013) If Words Could Speak: A Musical History of Hip-Hop's Golden Age. Wesleyan University, Middletown.

Dertouzos, J. N. (2008) Radio Airplay and the Record Industry: An Economic Analysis, Network. doi: 10.1145/2660267.2660334.

Diawangsa, R. (2014) Pemberdayaan Komunitas dan Eksistensi Musik Kendang Kempul di Media Penyiaan Komunitas (Studi Kasus Pada Radio Komunitas Citra FM Banyuwangi). Universitas Airlangga.

Driscoll, C. and Gregg, M. (2010) "My profile: The ethics of virtual ethnography," Emotion, Space and Society, 3(1), pp. 15-20. doi: 10.1016/j.emospa.2010.01.012.

Driskell, R. B. and Lyon, L. (2002) "Are Virtual Communities True Communities? Examining the Environments and Elements of Community," City and Community, 1(4), pp. 373-390. doi: 10.1111/1540-6040.00031.

Fay, M. (2007) "Mobile subjects, mobile methods: Doing virtual ethnography in a feminist online network," Forum Qualitative Sozialforschung, 8(3). doi: 10.17169/ fqs8.3.278.

Fine, G. A. (2003) “Towards a Peopled Ethnography," Ethnography, 4(1), pp. 41-60. doi: $10.1177 / 1466138103004001003$.

Hair, N. and Clark, M. (2003) “An Enhanced Virtual Ethnography: The Role Of Critical Theory," Exploring the meaning of'critique'in ..., 44(0). Available at: http:// merlin.mngt.waikato.ac.nz/ejrot/cmsconference/2003/proceedings/expl oringthemeaning/Hair.pdf.

Haryono, T. and Ganap, V. (2011) “Campursari Manthous : Antara Musik Jenis Baru Dan Fenomena Sosial Masyarakat Pendukung," Harmonia - Journal of Arts Research and Education, 11(2), pp. 115-124. doi: 10.15294/harmonia.v11i2.2204.

Hidayati, F. (2012) Etnografi Madura: Budaya Musik Daerah Etnis Madura. Universitas Airlangga.

Hidayatullah, P. (2015) "Musik Adaptasi Dangdut Madura," Resital, 16(1), pp. 1-14. Available at: http://journal.isi.ac.id/index.php/resital/article/view/1270/212.

Hine, C. (2000) Virtual Ethnography. London: Sage Publications Ltd.

Ida, R. (2008) “Consuming Taiwanese boys culture:Watching Meteor Garden with urban Kampung women in Indonesia," in Heryanto, A. (ed.) Popular Culture in Indonesia: Fluid identities in post-authoritarian politics. New: Routledge, pp. 93-110.

Ida, R. (2009) Watching Indonesian Sinetron: Imagining Audience in front of Television. Berlin: VDM Mueller.

Ida, R. (2017) “Budaya Global, Modernitas, dan Identitas Budaya: Perspektif Teoritik," in Ida, R. (ed.) Budaya Populer Indonesia, Diskursus Global/Lokal dalam Budaya Populer Indonesia. Surabaya: Airlangga University Press, pp. 18-20.

Iwabuchi, K. (2002) Recentering globalization: Popular culture and Japanese transnationalism. Edited by D. U. Press. Durham and London.

Jurriens, E. (2006) Ekspresi Lokal dalam Fenomena Global: Safari Budaya dan Migrasi. Jakarta: LP3ES dan KITLV.

Juwariyah, A. and Dharmawanputra, B. (2017) “Hibriditas Musik Dangdut OM SAGITA 
Menembus Pasar Industri Kreatif," in Hibriditas Dalam Ekologi Seni di Indonesia. Surabaya: FBS Unesa, pp. 1-6.

Kobi, M. F. (2017) “Campursari: Bentuk Lain dari Kesenian Gamelan yang Diterima di Masa Modern," Warna, 1(1), pp. 1-20.

Kriyantono, R. (2020) Teknik Praktis Riset Komunikasi Kuantitatif dan Kualitatif. Jakarta: Prenada Media Group.

Kuntowijoyo (1987) Tema Islam Dalam Pertunjukan Rakyat Jawa: Kajian Aspek Sosial, Keagamaan dan Kesenian. Yogyakarta: Depdikbud (Proyek Penelitian dan Pengkajian Kebudayaan Nusantara [Javanologi]).

Kusnadi (2006) "Melodi dan Lirik Lagu Campursari Ciptaan Manthous," Imaji, JURNAL SENI DAN PENDIDIKAN SENI, 4(1), pp. 109-123.

Liebowitz, S. J. (2005) “The Elusive Symbiosis: The Impact of Radio on the Record Industry," SSRN Electronic Journal, 1(1), pp. 93-118. doi: 10.2139/ssrn.520022.

Manthous (1999) "Campursari Harus Pener dan Bener," in Sarasehan Musik Campursari. Yogyakarta: Purna Budaya.

Mu-azu, I. A. and Shivram, G. P. (2017) “The Impact of Radio Broadcast in Local Dialect on Rural Community," Journal of Applied and Advanced Research, 2(3), p. 114. doi: 10.21839/jaar.2017.v2i3.76.

Muttaqin, M. (2006) “Musik Dangdut dan Keberadaannya di MAsyarakat: Tinjauan dari Segi Sejarah dan Perkembangannya," Harmonia, VII(2).

Noone, L. (2013) Radio in the Digital Age: The Evolution of Radio Culture in A New Media Era. University of Dublin, Trinity College.

Nurullita, H. (2015) Perjuangan Mencari Identitas: Perkembangan Damarwulan, Gandrung dan Musik Lokal Banyuwangi 1930an-2008. Universitas Gadjah Mada, Yogyakarta.

Prasetyo, A. B. (2018) Jejak sang Legendaris Ki Nartosabdo Dalang Terbaik dan Tak Tergantikan, MILESIA. Available at: https://milesia.id/2018/05/10/jejak-sanglegendaris-ki-nartosabdo-dalang-terbaik-dan-tak-tergantikan/ (Accessed: December 22, 2019).

Putradarma, R. (2017) "Subkultur Hiphop Indie Label di Yogyakarta: Sebuah Alternatif atau Siasat dalam Menciptakan 'Pasar' Baru?," Jurnal Pemikiran Sosiologi, 4(2), pp. 1-18.

Sade-Beck, L. (2004) “Internet Ethnography: Online and Offline," International Journal of Qualitative Methods, 3(2), pp. 45-51. doi: 10.1177/160940690400300204.

Saputri, T. S. (2015) CAMPURSARI "Nyanyian Hibrida dari Jawa" (Sebuah Video Dokumenter Tentang Polemik Keberadaan Campursari sebagai Tradisi Musik Baru di Dunia Seni Pertunjukan). Universitas Sebelas Maret Surakarta.

Saputro, H. and Sitorus, S. (1994) "Dangdut Masuk Rumah Gedongan," Majalah Femina, p. No. 26/XXII, 7-13 Juli.

Schaap, F. (2002) The Words That Took Us There. Ethnography in a Virtual Reality. Amsterdam: Aksant Academic Publishers.

Schramm, H. (2006) "Consumption and Eff ects of Music in the Media," COMMUNICATION RESEARCH TRENDS, 25(4), pp. 3-29.

Setiaji, D. (2017) “Tinjauan Karakteristik Dangdut Koplo Sebagai Perkembangan Genre Musik Dangdut," Handep, 1(1), pp. 1-16.

Shim, D. (2006) "Hybridity and the Rise of Korean Popular Culture in Asia," Media, Culture E Society, 28(1), pp. 25-44. doi: 10.1177/0163443706059278.

Shim, D., Heryanto, A. and Siriyuvasak, U. (eds.) (2010) Pop culture formations across East Asia. 1st-p'an ed. Seoul: Jimoondang.

Shumar, W. and Madison, N. (2013) "Ethnography in a virtual world," Ethnography and Education, 8(2), pp. 255-272. Available at: https://doi.org/10.1080/17457823.2013.792513.

Sinaga, M. (2016) Deskripsi Musik Campur Sari Grup Krido Laras Dalam Konteks Hiburan 
Pada Masyarakat Jawa Di Kota Medan. Universitas Sumatera Utara.

Sinclair, J., Jacka, E. and Cunningham, S. (2000) "Peripheral Vision," in Lechner, F. J. and Boli, J. (eds.) The Globalization Reader. Massachusetts: Blackwell Publishers, pp. 301-306.

Siwi, G. W. R. (2015) Musik Populer Kendang Kempul Banyuwangi. Institut Seni Indonesia, Yogyakarta.

Straubhaar, J. D. (1991) "Beyond media imperialism: Assymetrical interdependence and cultural proximity," Critical Studies in Mass Communication, 8(1), pp. 39-59. doi: 10.1080/15295039109366779.

Sugiarto, A. (1999) Kumpulan Gendhing Jawa Karya Ki Nartosabdo 2, Proyek Pengembangan Seni Budaya Daerah Jawa Tengah. Edited by A. Sugiarto. Semarang: Pemerintah Provinsi Daerah Tingkat I Jawa Tengah.

Supanggah, R. (2003) "Campursari: a Reflection," Asian Music. Texas: University of Texas Press, XXXIV(2), pp. 1-20.

Tallapessy, A., Setiawan, I. and Subaharianto, A. (2016) Transformasi Wacana dalam Lagu Pop-Etnis: Strategi Komersil dan Negosiasi Lokalitas dalam Industri Musik di Jawa Timur dan Jawa Tengah. Jember.

Uimonen, H. (2017) "Beyond the playlist: Commercial radio as music culture," Popular Music, 36(2), pp. 178-195. doi: 10.1017/S0261143017000071.

Wadiyo et al. (2011) "Campursari Manthous: Antara Musik Jenis Baru dan Fenomena Sosial Masyarakat Pendukung," HARMONIA: Jurnal Pengetahuan dan Pemikiran Seni, 11(2), pp. 115-124.

Wadiyo, Wiyoso, J. and Haryono, S. (2002) "Campursari Musik Etnis Jawa Populer antara Karya Manthous dan Didi Kempot," Lingua Artistika, 3(XXV), pp. 137-149.

Weintraub, A. N. (2013) "The Sound and Spectacle of Dangdut Koplo: Genre and Counter-Genre in East Java , Indonesia," Asian Music, 44(2), pp. 160-194. doi: 10.1353/amu.2013.0019.

Wimmer, R. D. and Dominick, J. R. (2014) Mass Media Research: An Introduction. 10th ed. Boston: Wadsworth, Cengage Learning.

Wiyoso, J. (2007a) "Campursari suatu Bentuk Akulturasi Budaya dalam Musik Indonesia," Harmonia. Yogyakarta, 8(3). doi: 10.15294/harmonia.v8i3.775.

Wiyoso, J. (2007b) “Jejak Campursari (The History of Campursari)," Harmonia, Jurnal Pengetahuan dan Pemikiran Seni, VIII(2), pp. 108-116.

Yoga, P. D. (2013) "Hubungan antara Musik Dangdut Koplo dan Lingkungan Gang Dolly," APRON Jurnal Pemikiran Seni Pertunjukan, 2(2). Available at: http://jurnalmahasiswa.unesa.ac.id/index.php/apron/article/view/3457.

Zein, K. and Dewi, S. I. (2019) "Peran Program Rojhek Cingur Radio Nada Fm Dalam Melestarikan Budaya Lokal Di Sumenep Madura," Jurnal Komunikasi Nusantara, $1(1)$, pp. 25-33. 